\title{
Multiculturalism of the modern city as a necessary condition for the modification of music-pedagogical education
}

\author{
Marina Osenneva ${ }^{1 *}$ and Chen Ying $^{1}$ \\ ${ }^{1}$ Moscow Pedagogical State University, Department of Methodology and Technology of Music \\ Education Pedagogy, Institute of Fine Arts, Moscow, Russia
}

\begin{abstract}
The article substantiates the need to integrate pedagogical communities in the context of multiculturalism as a social reality of contemporary urban life. The authors note the unity of the existence of such a phenomenon in the multicultural megacities of the polyethnic world in general, and in Russia and China, in particular. Nevertheless, training future teachers to multicultural music education is usually carried out locally based on the students' country of residence, which today requires concerted efforts on the part of teachers-musicians of different countries, including Russia and China, of which each has its own view on the solution to this issue and a wealth of experience in the formation and development of students' respect for different musical cultures within the country, in general, and metropolises, in particular. In this regard, the research aims to study the theoretical justification and testing of technologies for students to master the multicultural component of music education in the Russian Federation and China in the comparative context. To achieve this goal, the authors used theoretical and empirical methods. The scientific novelty of the research is based on a comparative analysis of the methodological foundations, the essence and content of the multicultural component of the music programs of the Russian Federation and China, as well as identification of common and characteristic features of pedagogical approaches, general and specific methods of multicultural education in the Russian Federation and China. The reliability and validity of the research results are proven by relying on the fundamental provisions of science, as well as consideration of the research problem from the standpoint of philosophical, general scientific, and specific scientific analysis.
\end{abstract}

Keywords: a dialogue of cultures, cultural pluralism, content, methods.

\section{Introduction}

Contemporary approaches to comparative pedagogy are characterized by concepts that provide for the integration of pedagogical communities due to the globalization of world processes. This orientation of pedagogical innovations makes it possible to overcome the

* Corresponding author: marina-osenneva@yandex.ru 
existing contradiction that has become characteristic of the multicultural world in general, and of Russia and China, in particular.

Thus, it has become a common belief that the principle of multiculturalism in education is important and necessary because of the relevance of promoting mutual understanding of peoples, recognizing the diversity of cultures of different ethnic groups, and respecting the uniqueness and value of the cultures of a multicultural world. The following regulatory documents are clear proof:

1. of a global nature:

- the UN: $21^{\text {st }}$-century education programs

- the UNESCO Universal Declaration on Cultural Diversity; reports on "Learning in order to be", "On human development", "Education is a hidden treasure"; "Education in a multicultural world", etc.

- the International Society for Music Education (ISME): Resolutions of international conferences on the education of respect for national cultures and the actualization of international understanding between East and West

2. of national standing:

- the law of the Russian Federation "On education", "National doctrine of education in the Russian Federation", and "National plan for medium and long-term education reform and development" of the Peoples Republic of China (PRC).

Such interest in the problem of multiculturalism can be explained by the multinational nature of the Russian Federation and China. In this regard, the multicultural component has become the most important component in the content of general education, as well as music, in particular, both in the Russian Federation and China. Moreover, in the models of multicultural music education in Russia and China, not only the local and national levels of the multicultural component were implemented, but also the world level. Nevertheless, training future teachers to multicultural music education is usually carried out locally based on the students' country of residence, which today requires concerted efforts on the part of teachers-musicians of different countries, including Russia and China, of which each has its own view on the solution to this issue, and a wealth of experience in the formation and development of students' respect for different musical cultures within the country, in general, and metropolises, in particular.

The purpose of the study concerns theoretical justification and testing of technologies for students to master the multicultural component of music education in large metropolises of the Russian Federation and China in the comparative context.

The research hypothesis is formulated as follows:

pedagogical conditions for mastering the multicultural component of music education by students' in major metropolises of Russia and China in the comparative context require the use of the following technologies in the professional preparation of teacher:

- humanitarian education of dialogue/polylogue, implementing the educational aspect of the concerned problem;

- modular learning technologies that allow didactically structuring the educational process of mastering the multicultural component of music education in large metropolises of the Russian Federation and China in the comparative context;

- media technologies to create methodological digital support for students' mastering the phenomenon of multiculturalism in music education in a large metropolis.

The following research objectives were set:

- to consider methodological approaches to identifying the essence of the multicultural component of the music programs content of the Russian Federation and China in the context of comparative pedagogy;

- to develop and test methods and technologies for students to master the multicultural music education model in a large multinational metropolis. 
The scientific novelty of the research is proved by the following achievements:

- methodological foundations, essence, and content of the multicultural component of the music programs of the Russian Federation and China have been revealed;

- common and characteristic features of pedagogical approaches, general and specific methods of multicultural education of the Russian Federation and China have been defined;

- a multicultural music education model for students of the Russian Federation and China in a large multinational metropolis has been developed and tested.

\section{Methods and methodological framework}

Methods of research: theoretical (philosophical, general scientific, specific scientific analysis of the literature on the research problem), and empirical (experiment involving control, forming, and verification stages).

The methodological framework of the research:

- philosophical ideas of the dialogue of cultures (N.K. Roerich [1]) and philosophical foundations of multicultural education (Guan Jianhua [2]);

- conceptual framework of the ethnic pedagogy (G.N. Volkov [3]), cultural studies (M.S. Kagan [4]), music studies (V.V. Medushevsky [5]), music psychology, and psychology of music education (A.V. Toropova [6]).

- the theory of harmonization of universal and national values (N.D. Nikandrov [7], and Wang Jian [8]), multiculturalism in education (O.V. Gukalenko [9], Wang Xi [10]);

- research in the field of comparative pedagogy (A.N. Dzhurinsky [11], and comparative music pedagogy (E.A. Bodina [12], Zhao Nannan [13]);

- research of Russian and Chinese teachers in the pedagogy of music education (E.B. Abdullin [14], Xie Jiaxing [15]);

- research in the field of multicultural music education (L.S. Maykovskaya [16], Shi Zhongying [17], and others);

- writings in the field of higher school pedagogics technology (V.A. Sitarov [18], Wang Daojun [19]) and, in particular, in terms of musical-pedagogical education (E.V. Nikolayeva [20], L.A. Rapatskaya [21], Feng Lanfang [22], and others).

\section{Results}

Analysis of psychological, pedagogical, and special literature has shown that the effectiveness of music teacher training in the context of globalization was promoted using the model developed by the authors, and tested experimentally in the context of a large metropolis in the Russian Federation and China (Fig. 1). 


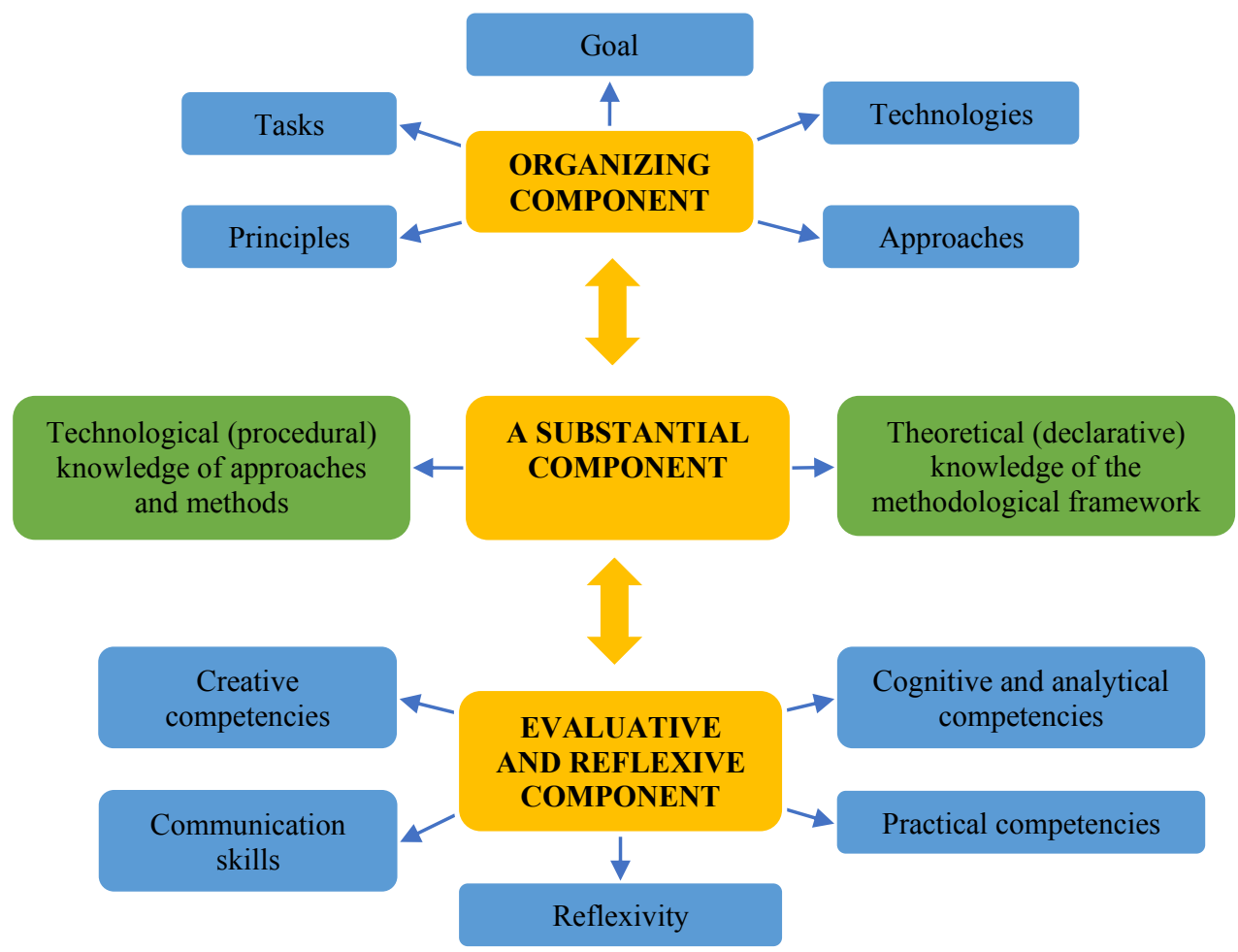

Fig. 1. Diagram of the developed model.

The model of musical and pedagogical multicultural education tested experimentally, is based on the analysis of the writings of prominent Russian and Chinese teachers having a common understanding of the issue, namely:

- the goal of implementing multicultural music education in large metropolises as the formation of the musical culture of students on an ethnonational basis,

- the content of the multicultural music education category, as organic synthesis of emotional and value ideas, musical knowledge, and skills of creative self-actualization in various types of musical activities based on traditional and professional creativity of different peoples.

In this regard, the model presented in the study provided for the formation of motivational and value, analytical and cognitive, practical, creative, and communicative competencies, potentially aimed at:

- educating ethnocultural tolerance (L.S. Maykovskaya) as mutual respect for the national identity of different peoples;

- developing students' social needs in mastering the richness of the traditional and professional culture of various peoples inhabiting multinational large metropolises;

- forming in students the ideas about the universal values of musical culture and the experience of international relations in the field of musical creativity.

Comparing the results of the ascertaining and testing stages, it is easy to establish positive dynamics of indicators in the experimental group, and in particular, the prevalence of high rates, while reducing the medium and low rates (Fig. 2). 


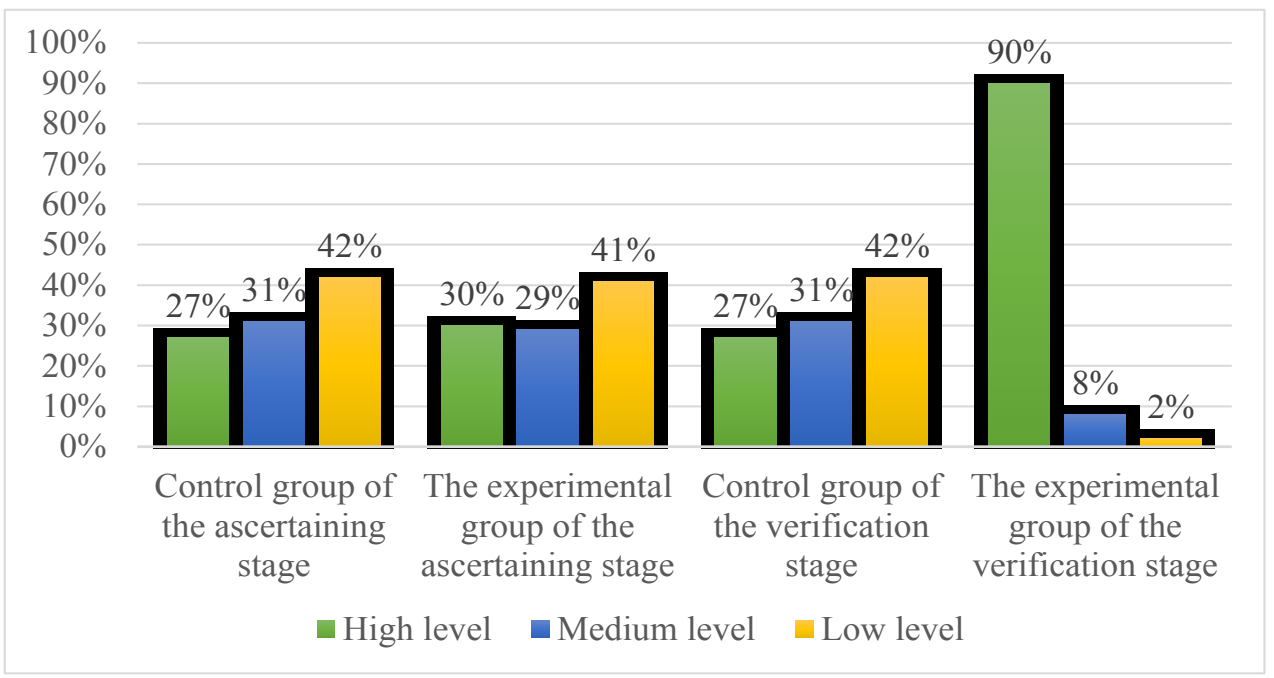

Fig. 2. Comparative diagram.

\section{Discussion}

The higher indicators of the experimental group are explained by the use of intonation, musicology, cultural studies, and activity-based approaches in the comparative study of multicultural music education in large megacities of Russia and China in the course of the formative stage.

The work of students of the experimental group with the musical content of Russian and Chinese authors has contributed to finding not only common but also single goal sets, namely:

- principles based on the strategic ideas of peace in the world: pluralism and equality;

- methods of multicultural music education;

- methodological approaches to the implementation of educational, developmental, and training tasks for conscious perception by students of the ethnomusicological content of the peoples inhabiting a multinational metropolis.

\section{Conclusion}

A comparative study of the multicultural component of the music programs in Russia and China has allowed students to identify problems and suggest possible solutions. Thus, forming a culture of interethnic relations in a multilingual world of a large metropolis, children's familiarization with traditional musical culture should be based not only on national categories, such as ethnic music, traditions, history, ethnic pedagogy but also on language, which will contribute to the formation of the unity of people of different national cultures. The traditional approach to mastering music of various peoples in the original languages in the system of additional music education can become an analog for general music education in large metropolises of Russia, while in China - a model for mastering the music of national minorities in the language of ethnic groups. 


\section{References}

1. N.K. Roerich, Synthesis. Collection "Culture and civilization", 108-109 (Moscow, ICR, 1997)

2. Guan Jianhua, 建华管// 音乐艺术 [Music and Performance], 1, 127-136 (2009)

3. G.N. Volkov, Ethnopedagogy: Textbook for students of secondary and higher pedagogical institutions (Publishing Center Academiya, Moscow, 1999)

4. Yu.N. Solonina, M.S. Kagan (Eds.) Culturology: Textbook (Vyssheye obrazovaniye, Moscow, 2007)

5. V.V. Medushevsky, Spiritual analysis of music: in two parts, 2nd ed. (Kompozitor, Moscow, 2016)

6. A.V. Toropova, Intonating nature of the psyche: musical and psychological anthropology (MPGU, Moscow, 2018)

7. N.D. Nikandrov, School library, 2, 19-25 (2008)

8. Jian Wang, Minggang Wan, 广西民族研究 [Guangxi Ethnic Studies], 2, 21-28 (2004)

9. O.V. Gukalenko, Educational space of Russia: unity in diversity (Energiya, Moscow, 2016)

10. Xi Wang, 美国研究 [American studies], 2, 43-80 (2000)

11. A.N. Dzhurinsky, Comparative pedagogy (Yurayt, Moscow, 2020)

12. Ye. A. Bodina, Musical pedagogy and art pedagogy. Concepts of the XXI century: textbook for universities (Yurayt, Moscow, 2020)

13. Zhao Nannan, M.S. Osenneva, Model of the implementation of a cross-cultural approach to the development of the didactic functions of textbooks for general primary music education in Russia and China by future music teachers in: Actual scientific research: Collection of scientific articles, 208 -212 (Editoria di Rome, Italy, 2018)

14. E.B. Abdullin, O.F. Asatryan, Humanities and education, 4(28), 113-118 (2016)

15. Xie Jiaxing, Yu Wenwu, 高等教育出版社 [Higher Education Press] (2006)

16. L.S. Maykovskaya, P.A. Chervatyuk, A.P. Mansurova, On the issue of the problems and specifics of teaching foreign students in Russian universities, in: Actual problems of improving the pedagogical skills of teachers of higher education: Collection of articles by teachers, graduate students, applicants, participants in the scientific and methodological interuniversity conference of Moscow State Institute of Culture, 103108, (Econ-Inform, Moscow, 2018)

17. Shi Zhongying, 教育科学研究 [Educational Science Research], 10, 8-11 (2003)

18. V.A. Sitarov, Teaching theory. Theory and practice: a textbook for bachelors (Yurayt, Moscow, 2016)

19. Wang Daojun, Guo Wenan, 人民教育出版社 [People's Education Press] (2016)

20. Ye.V. Nikolayeva, Bulletin of the UNESCO Chair "Musical Art and Education", 4, 145-162 (2018)

21. L.A. Rapatskaya, Tsennosti i smysly, 56, 6-14 (2016)

22. Feng Lanfang, 首都师范大学出版社 [Capital normal university] (2016) 